\section{COVID-19 Pandemic in the Caribbean}

\author{
Damion Basdeo ${ }^{1}$, Loren De Freitas ${ }^{2}$ \\ ${ }^{1}$ Department of Internal Medicine, Sangre Grande \\ Hospital, Eastern Regional Health Authority \\ ${ }^{2}$ Arima District Health Facility, North Central Regional \\ Health Authority
}

\section{Corresponding Author:}

Damion Basdeo (MBBS, UWI)

Department of Internal Medicine

Sangre Grande Hospital

Eastern Regional Health Authority

Trinidad and Tobago

Email: damionbasdeo@yahoo.com

DOI: $10.48107 / C M J .2020 .12 .002$

\section{Copyright:}

This is an open access article under the terms of the Creative Commons Attribution License which permits use, distribution and reproduction in any medium, provided the original work is properly cited.
"Beginnings are usually scary, and endings are usually sad, but it's everything in between that makes it all worth living. "- Bob Marley

The above quote is aptly applicable to the COVID-19 pandemic. By now, we all are quite familiar with the COVID-19 virus. Amidst scientific discoveries, advancements in medicine and eradication of diseases, we are hit by this global crisis. The pandemic has now resulted in more than $\mathbf{4 0}$ million infected persons and over one million preventable deaths. The virus knows no limits, and all classes, races, ethnic and cultural groups are affected, notwithstanding the fact that some groups are more affected than the others.

"You take it for granted... When it's taken away from you, you realize that just being here is a blessing", said Dr. Eric Williams. This is a reminder of the freedoms we have lost, as a result of the restrictions implemented in our countries. The Caribbean islands now face a great challenge. In our efforts to protect and save lives, many sacrifices have been made. The implemented public health measures are now common knowledge. Our 'new normal' includes wearing face masks, washing hands, physically distancing and seeking credible medical advice. Our health systems and health care workers have done remarkably well for our limited resources.

It's now time for us to "Rally round the West Indies" and fight this pandemic together. Our sisters and brothers in the medical fraternity are asked to continue our sterling efforts until we overcome this pandemic. As medical professionals we are now asked to run this race together, be the "Usain Bolt" of our profession and cross the finish line victorious. This may be long and arduous but our resilience shall prevail. We must continue to educate the public with the available strong scientific evidence and debunk the myths and misconceptions regarding this disease.

The Caribbean Medical Journal (CMJ) supports our medical community in its continued efforts to fight the pandemic. We also support the advancement of local and regional research which may be used to support the development of local clinical guidelines and our own policies backed by local scientific evidence. The CMJ 
Special COVID-19 series offers the opportunity to showcase research produced in the region, aiming to highlight local and regional work in both clinical and non -clinical areas pertinent to the pandemic. We hope that the series will encourage clinicians, researchers and other professionals to continue embarking on local and regional research.

We, as one of the leading medical journals from the region, should be instrumental in orchestrating every possible measure towards the containment of this pandemic. Let us continue to strive to give our best!

\section{REFERENCES}

1. Hunte SA, Pierre K, St Rose R. Health Systems' Resilience: COVID-19 Response in Trinidad and Tobago. The American Journal of Tropical Medicine and Hygiene 2020; 103(2): 590-592. https:// doi.org/10.4269/ajtmh.20-0561

2. Coley-Graham, T. Weathering the COVID-19 storm in the Caribbean. Inter-American Development Bank 2020. Retrieved from: https://www.iadb.org/en/ improvinglives/weathering-coronavirus-stormcaribbean. Accessed- 21/10/2020 